Mothers' Attitudes toward Their Children's Use of Digital Textbooks

\author{
د/ إلهام عبد الكريم السعدون

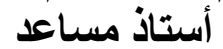 \\ كلية التربية - جامعة الملك سعود المباد \\ المملكة العربية السعودية \\ Elham Abdulkareem Alsadoon \\ Assistant Professor \\ Curriculum and Instruction Department \\ College of Education \\ King Saud University \\ Saudi Arabia
}




\title{
Mothers' Attitudes toward Their Children's Use of Digital Textbooks
}

\begin{abstract}
:
The current study aimed at investigating mothers' attitudes toward the use of digital textbooks. A total of 153 mothers of elementary school children in Saudi Arabia filled out an online survey. Results showed that mothers have positive attitudes toward using digital textbooks and a good degree of willingness to switch to the digital form. At the same time, they are aware of the disadvantages of digital textbooks. Suggestions for further studies were included. Keywords: digital textbooks, e-learning, elementary

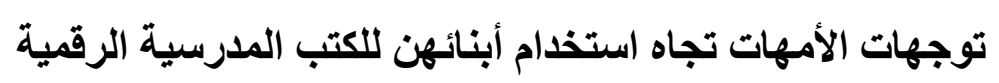
education.

هدفت الدر اسة إلى استقصاء اتجاهات الأمهات تجاه استخدام أبنائهم للكتب الدر اسية الرقمية.

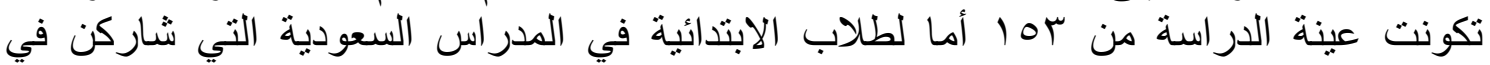
الاستطلاع الإلكتروني، وقد أظهرت النتائج أن المشاركات يحملن توجهات الايجابية تجاه استخدام

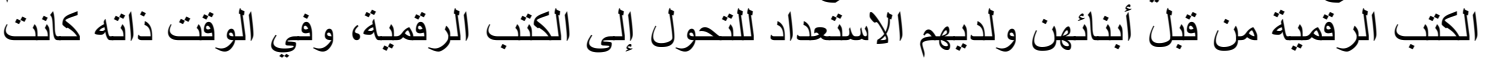

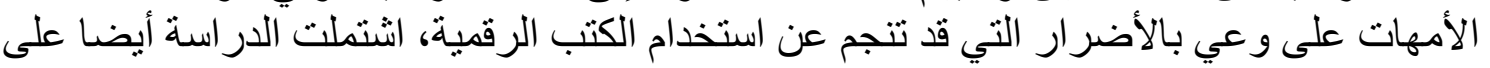
توصيات لبحوث ودر اسات مستقبلية.

$$
\text { الكلمات مفتاحية: الكتب الرقية لورية، التعليم الالكتروني، التعليم الابتدائي }
$$
\end{abstract}

\section{Introduction:}

In the 21 st century, many countries seek to implement technologies in the educational environments. One of the technologies that has gained wide interest is the digital textbook. In this educational era, digital books have become common among young learners and they were able to access many books. Saudi Arabia, through its Ministry of Education, is moving toward digital learning as it has launched an initiative to transform textbooks to digital one within three years (Alsahly, 2017).

Handheld digital book readers are rapidly becoming widespread in schools since they allow students and teachers to easily do necessary everyday jobs such as note taking, word processing, sketching, sending emails and browsing. Some devices allow users to print the digital books or e-books, support the use of video or audio formats, and allow internet access and communications. While these technologies can enhance the learning opportunities, they also carry a risk (Nives, Gordana \& Mirjana, 2016). Therefore, the use of digital textbooks can be a concern for parents who may not support the use of digital textbooks by their children at home. Parents who believe that their children should learn the value of technology, are encouraging their children to use digital books. 
Encouragement is vary according to the parents' attitudes toward technology (Strano, Hrachovec, Sudweeks \& Ess, 2012).

Parents' attitudes - especially parents of young pupils- toward the use of new technology in education is an important element of the success of its implementation. Researchers have explored students' attitudes toward the use of digital textbooks (Al Saadi, Lane-Kelso, Al Hafeedh , Al Sheithani \& Al Wishahi, 2017; Embong, Noor, Rafek, Othman, \& Khalid, 2014; Falc, 2013 ), but little research takes into consideration the parents' attitudes; consequently, such a gap should be addressed. Parents can influence their children's learning by providing them with the needed digital devices, encouraging them to develop positive attitudes toward their learning, and motivating them to learn (Winters, 2005). Therefore, this study seeks to gain insight into the attitudes of parents toward the use of digital textbooks in school. By gathering information that might help smooth the implementation process, this study will contribute to the literature of the use of digital textbooks in education and the replacement of printed textbooks.

\section{Literature Review:}

Technology has transformed all the aspects of students' lives today and will continue to do so. Education is one of the fields that has been affected by the advancement of technology from the use of small technologies in classrooms to moving the whole class into the virtual world. Textbooks also are being implemented and digital textbooks have become a new trend in Saudi Arabia (Alsahly, 2017). Ordinarily, technology brings new opportunities to enhance students' development in the learning experiences, communications skills, and personal skills. On the other hand, technology can be risky.

Consequently, parents are always concerned and are anxious about their children usage of technology, especially at a young age. Their concerns are focused mostly on the impact of technology on cognitive, emotional and social development (Nives, et al., 2016). Replacing printed books with digital textbooks might raise such concerns. On the other hand, many educators advocate the use of digital textbooks which they have found to support the implementation of the constructivist principles (Embong, 2014).

A digital book or e-book is "a text in digital form, or digital reading material, or a book in a computer file format, or an electronic file of words and images" (Rao, 2003, p. 86-87). E-books have three elements: the ebook itself or the content, the software used to read the content, and the hardware on which the content is read (Weber \& Cavanaugh, 2001; Cavanaugh, 2002). The content of an e-book file could be a text, an image 
or any other medium such as video or audio. Prior to the emergence of handheld devices, the most common way of delivering e-books was by CDROM and the internet. When such devices were used for the first time they were only for reading e-books, and then they were enhanced to access the internet, handle word processing and play media (Shiratuddin, Landoni, Gibb, \& Hassan 2003).

Lam, Lam, Lam, \& McNaught (2009) differentiated between e-books and e-journals in terms of length and structure. It is important to keep these two elements in mind when adopting the digital textbook technology in education. Reading a long academic book on an e-book reader would be markedly different than reading a short, focused article. This could affect students' satisfaction with replacing printed textbooks with digital textbooks.

There are two components of e-book reader: the first requirement is a special hardware and the second, is a software-based such as the Adobe Acrobat Reader, like that used on computer (Shiratuddin et al., 2003). The software-based type enable the learner to have a larger screen and a full keyboard when the e-book is displayed on a computer as well as the printing of a hard copy is desired.

With the technology advancements, e-books have acquired advantages over printed books. When digital books first emerged they had three advantages: a searching feature which allowed the user to find any word in the document (especially useful in large documents); the ability to modify the content which allow students to change the fonts to meet their needs and to add their own notes or images; and they were designed to enhance students' understanding through providing definitions, explanations, and other information regarding specific topics ( AndersonInman and Horney, 1997). These features helped in improving the students' literacy skills. Some e-books are available in more than one language, allowing students to choose the language that suits them best.

Moreover, students can take the advantage of highlighting, note taking and map drawing by which they can focus their attention on the main ideas just as they can highlight while reading paper-based books or add their own notes or concept maps. Other features of e-books are the annotation, bookmarking, and interactive dictionary functions (Simon, 2001; Cavanaugh, 2003; Wilson, 2003). Simon found that students value the glossary look-up feature but do not use the annotation feature very often because typing on a small screen is uncomfortable. Finally, e-books are easy to carry and one lightweight device allows students to carry thousands of books with one item (Lam et al., 2009; Kiriakova, Okamoto, Zubarev \& Gross, 2010). The e-book format keeps the file small, allowing 
storage of many e-books in a small memory thus solving the problem of the students having to carry large amounts of educational material. This portability also allows students to read anywhere at any time (Lam et al., 2009; Wilson, 2003).

The user-friendly display of the e-book page facilitates reading from digital devices (Doering, Pereira \& Kuechler, 2012). A whole page is presented at one time, eliminating the need to scroll down or up when reading. E-books also allow students to change the font size as they choose (Cavanaugh, 2003). Having the content read aloud is a feature of e-books available on some types of e-book readers. This is especially valuable for language students, students with vision problems and students with reading disabilities. It is also a valuable feature for students whose learning style is auditory. Students find the use of interactive features of e-book engaging (Al Saadi et al., 2017).

While the digital textbook can be an ideal solution for some of the problems of traditional education and have many advantages, they also have some drawbacks. For example, they need devises or machines to be read. If such books are read through handheld devices or computers, they require batteries, and if they are read from the internet, they require an internet connection. This means additional costs as well as internet access for the time needed for the reading (Anderson-Inman \& Horney, 1997). Lam et al. (2009) found in their study that the use of e-books in education is not practical for the following reasons: students did not enjoy reading in the digital format and the students' understanding of the text was challenged, as was dealing with technology for some students. They found that the use of e-books is affected by technology issues such as failing to download an e-book. These issues; consequently, affect how students' see the usefulness of the e-book.

In his study, Appleton (2004) found, as his participants believe that using e-book readers is time-consuming, the content is hard to manage, and only a limited number of books have been converted to an electronic version. The participants in Appleton's study stated that when a shared computer or device is used for e-book, the reading time is limited while printed books do not have to be shared with others. Reading e-books from a small handheld screen slows students down and makes viewing images difficult. Short battery life is another disadvantage of using these devices (Lam et al., 2009). According to Shiratuddin et al. (2003), these devices are not affordable, they display content poorly, and the number of books in an electronic format is still small. A recent study showed other disadvantages: many e-books are not globally available, using them may lead to headaches 
and eyestrain, and many available e-books lack the interactive features (Liaw \& Huang, 2014).

Despite their drawbacks, however, digital books have the potential to enhance learning (Lim and Hew, 2014; Sun et al., 2012) and many educational institutions have begun to adopt them and plan to spread them gradually while decreasing the use of printed books (Wu \& Chen 2011). Some studies, though, showed that students preferred printed books academic reading (Young, 2009; Buzzetto-More et al., 2007; Woody, Daniel \& Baker, 2010; Li, Poe, Potter, Quigley, \& Wilson, 2011; Edmondson, 2016). Digital textbooks may present some challenges if they are not the preferred form of instruction (Al Saadi, et al., 2017). Knowing the attitudes toward them help in smoothly implementing their use. The attitudes of the parents of young children is also important as they motivate their children to accept and use any technology and encourage them to develop positive attitudes toward it. A review of the available literature revealed that no study had addressed the parental attitudes toward the use of technology in learning (Strano, et al., 2012), especially the use of digital textbooks. This study may give insights to understanding the mothers' attitudes and thus help in planning for successful implementation.

\section{Method:}

Mothers of children at the elementary level participated in the study as they were asked to complete an online survey designed to collect data about mothers' attitudes toward the use of digital textbooks by their children. The survey was developed by the researcher based on the literature (Al Saadi, et al., 2017; Liaw \& Huang, 2014; Lim \& Hew 2014; Falc, 2013). It was examined for its validity and reliability. The survey contained two main constructs: advantages (11 items) and disadvantages ( 9 items) of using digital textbooks as well as other information in regards to the children's use of digital devices. It also included an open-ended question to collect other concerns mothers might have toward the use of digital textbooks in education. A convenience sample was drawn from mothers whose children were enrolled in public elementary schools. There were 153 mothers who voluntarily participated in the study. Confirmatory factor analysis (CFA) was conducted to verify the constructs validity of the survey. Cronbach's Alpha was calculated to confirm the reliability of the survey construct. Table (1) shows the reliability of two constructs of the survey: perceived advantages and perceived disadvantages of using digital textbooks in education as well as their means and standard deviation.

Table 1: Reliability statistics for the survey's construct $(\mathrm{N}=153)$.

\begin{tabular}{rrrrrr}
\hline Construct & Cronbach's Alpha & $\begin{array}{c}\text { N of } \\
\text { Items }\end{array}$ & Mean & \multicolumn{1}{c}{ SD } \\
\hline Perceived advantages & .963 & 11 & 3.84 & .87
\end{tabular}




$\begin{array}{rllll}\begin{array}{r}\text { Perceived } \\ \text { disadvantages }\end{array} & .958 & 9 & 3.79 & .94 \\ \text { Results: } & \end{array}$

Table (2) displays the age of the participants and the normality of distribution. Analyzing the availability of the digital devices such as desktop computers, laptops, tablets, smartphones, etc. All the participants' homes had at least one digital device that could access the internet and half of them fell in the range of one to five devices at home. Table (3) displays the numbers of devices participants have at home. In regard to whether their children use these digital devices for their learning, $22 \%$ of the participants answered that their children always use these devices versus $5 \%$ who answered "never". The majority of them (56\%) answered "sometimes" and 17\% said "Seldom". Table (4) displays the distribution. In respect to the activities for which participants' children use digital devices, almost all participants' children use such devices for watching videos and a small proportion of them read e-books with these devices. Other activities were playing games $(76 \%)$, exploring the internet $(55 \%)$, communicating with others (51\%) and using apps (49\%). Table (5) displays participants' children's use of digital devices. Table (6) displays participants' children's possession of digital devices and shows that $72 \%$ of the children whose mothers participated in the study own their own digital devices.

Table 2: Age of participants

\begin{tabular}{ccc}
\hline Age & $\mathbf{N}$ & \% \\
\hline$<=29$ & 32 & $21 \%$ \\
$\mathbf{3 0 - 3 9}$ & 61 & $40 \%$ \\
$\mathbf{4 0 - 4 9}$ & 57 & $37 \%$ \\
$\mathbf{5 0 +}$ & 3 & $2 \%$ \\
\hline Total & 153 & $100 \%$ \\
\hline
\end{tabular}

Table 3: Numbers of devices participants have at home.

\begin{tabular}{rrr}
\hline Number of devices & $\mathbf{N}$ & $\mathbf{\%}$ \\
\hline $\mathbf{0}$ & 0 & 0 \\
$\mathbf{1 - 5}$ & 87 & $57 \%$ \\
$\mathbf{6 - 1 0}$ & 53 & $35 \%$ \\
$\mathbf{1 0 +}$ & 13 & $8 \%$ \\
Total & 153 & $100 \%$ \\
\hline
\end{tabular}

Table 4: Frequency of participants' children use of digital devices in learning

\begin{tabular}{ccc}
\hline How often & $\mathbf{N}$ & $\%$ \\
\hline Always & 33 & $22 \%$ \\
Sometimes & 86 & $56 \%$ \\
Seldom & 26 & $17 \%$ \\
Never & 8 & $5 \%$ \\
\hline Total & 153 & $100 \%$ \\
\hline
\end{tabular}


Table 5: Participants' children's use of digital devices

\begin{tabular}{rrr}
\hline Usage & $\mathbf{N}$ & $\mathbf{\%}$ \\
\hline Watching videos & 132 & $86 \%$ \\
Playing games & 116 & $76 \%$ \\
Exploring internet & 84 & $55 \%$ \\
Communicating with others & 78 & $51 \%$ \\
Using apps & 75 & $49 \%$ \\
Reading E-books & 13 & $8 \%$ \\
\hline
\end{tabular}

Table 6: Participants' children's possession of digital devices

\begin{tabular}{rrr}
\hline Possession & N & \% \\
\hline No & 43 & $28 \%$ \\
Yes & 110 & $72 \%$ \\
\hline Total & 153 & 100
\end{tabular}

Analyzing mothers' views about the advantages and disadvantages of using digital textbooks by their children showed that all participants hold positive attitudes toward the use of digital textbooks because they hold positive attitudes toward the use of technology in education in general as well. The item "The use of technology in school is one of the factors that distinguishes one school from another" has mean $=4.0$. Mothers' attitudes regarding the advantages and disadvantages of digital textbooks for their children were measured on a 5 -point Likert scale $(1=$ strongly disagree, and $5=$ strongly agree).

Positive attitudes of the parents toward their children's use of digital textbooks are indicated by their high level of agreement with statements 3 14 in Table 7 and by the mean of the advantages construct $(M=3.84$, $\mathrm{SD}=.87$ ). The digital-textbook advantage that gained the highest mean was "Using digital textbooks will solve the problem of heavy book bags" ( $\mathrm{M}=$ 4.37), $\mathrm{SD}=.84$, followed by "Using digital textbooks will enable using multimedia in learning" $\mathrm{M}=4.08, \mathrm{SD}=1.0$, "Using digital textbooks will facilitate students' access to information" $(\mathrm{M}=4.04)$, and "Using digital textbooks will facilitate accessing learning content from anywhere" (M= 4.03).

Results showed that participants were aware of the disadvantages of digital textbooks for their children, the total mean of the disadvantages construct was $3.8, \mathrm{SD}=.9$. However, they believe "The advantages of digital textbooks outweigh their disadvantages" $\mathrm{M}=3.3, \mathrm{SD}=1.0$. The disadvantage that gained the highest agreement was "Using digital textbooks will cause eye strain" $\mathrm{M}=4.05$, SD 1.1. Table 7 displays the items in the scale as well as the mean for each item. 
Table 7: Mean and standard of the survey items.

\begin{tabular}{|c|c|c|c|}
\hline & Items & Mean & SD \\
\hline 1 & $\begin{array}{l}\text { The use of technology in school is one of the } \\
\text { factors that distinguishes one school from another }\end{array}$ & 3.99 & 1.094 \\
\hline 2 & Transforming textbooks to digital form is essential & 3.49 & 1.131 \\
\hline 3 & $\begin{array}{r}\text { The advantages of digital textbooks outweigh their } \\
\text { disadvantages }\end{array}$ & 3.34 & 1.083 \\
\hline 4 & $\begin{array}{c}\text { Using digital textbooks will improve education } \\
\text { quality }\end{array}$ & 3.40 & 1.173 \\
\hline 5 & $\begin{array}{r}\text { Using digital textbooks will improve students' } \\
\text { digital skills }\end{array}$ & 3.78 & 1.096 \\
\hline 6 & $\begin{array}{r}\text { Using digital textbooks will facilitate students' } \\
\text { access to information }\end{array}$ & 4.04 & .966 \\
\hline 7 & Using digital textbooks will enhance learning & 3.69 & 1.079 \\
\hline 8 & $\begin{array}{r}\text { Using digital textbooks will help in providing } \\
\text { interactive learning }\end{array}$ & 3.83 & 1.018 \\
\hline 9 & $\begin{array}{c}\text { Using digital textbooks will facilitate students' } \\
\text { access to interactive learning activities }\end{array}$ & 3.91 & 1.028 \\
\hline 10 & $\begin{array}{r}\text { Using digital textbooks will enhance students' } \\
\text { creativity }\end{array}$ & 3.61 & 1.028 \\
\hline 11 & $\begin{array}{r}\text { Using digital textbooks will facilitate accessing } \\
\text { learning content from anywhere }\end{array}$ & 4.03 & .979 \\
\hline 12 & $\begin{array}{c}\text { Using digital textbooks will enable using } \\
\text { multimedia in learning }\end{array}$ & 4.08 & 997 \\
\hline 13 & Using digital textbooks is easy & 3.78 & 1.034 \\
\hline 14 & $\begin{array}{r}\text { Using digital textbooks will solve the problem of } \\
\text { heavy book bags }\end{array}$ & 4.37 & .835 \\
\hline 15 & $\begin{array}{r}\text { Using digital textbooks will negatively impact } \\
\text { students' health }\end{array}$ & 3.91 & 1.054 \\
\hline 16 & Using digital textbooks will cause eye strain & 4.05 & 1.126 \\
\hline 17 & $\begin{array}{r}\text { Using digital textbooks will negatively impact } \\
\text { students' social skills }\end{array}$ & 3.78 & 1.166 \\
\hline 18 & $\begin{array}{l}\text { Using digital textbooks will increase financial } \\
\text { expenses (Internet cost, cost of devices) }\end{array}$ & 3.77 & 1.123 \\
\hline 19 & $\begin{array}{c}\text { Using digital textbooks will bring technical } \\
\text { problems that hinder students' learning }\end{array}$ & 3.87 & .951 \\
\hline 20 & $\begin{array}{r}\text { Using digital textbooks will distract students from } \\
\text { learning }\end{array}$ & 3.72 & 1.097 \\
\hline 21 & $\begin{array}{c}\text { Using digital textbooks will interrupt learning } \\
\text { because of the short life of batteries }\end{array}$ & 3.63 & 1.063 \\
\hline 22 & Using digital textbooks will make reading hard & 3.68 & 1.129 \\
\hline
\end{tabular}


because of the small size of screen

23 Using digital textbooks will expose students to $3.56 \quad 1.165$

risk through handling wires and electrical plugs

Even though only a few participants responded to the open-ended question intended to collect data about other concerns mothers have when their children use digital textbooks, other concerns of such use were raised. They are displayed in Table (8).

Table 8: Participants' responses to the open-ended question about other concerns with using digital textbooks.

\begin{tabular}{|c|c|}
\hline Items & Frequency \\
\hline 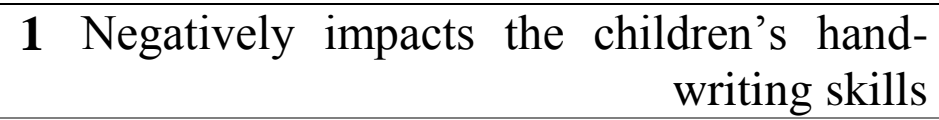 & 4 \\
\hline $\begin{array}{cc}\text { impacts } & \begin{array}{c}\text { retention of } \\
\text { information }\end{array}\end{array}$ & 3 \\
\hline 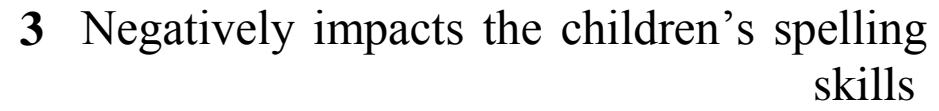 & 2 \\
\hline Not suitable for all subjects & 1 \\
\hline 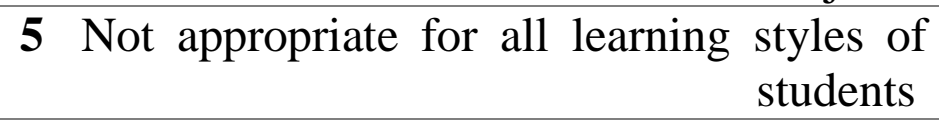 & 1 \\
\hline
\end{tabular}

\section{Discussion:}

Digital textbooks are relatively new technology. Some studies have explored the learners' attitudes toward e-book use. Implementing them into K-12 needs more exploration into its suitability. Since the students in K-12 are influenced by their parents, especially mothers who usually spend much time helping their children to learn at home, it was important to shed some light on the mothers' attitudes toward their children's use of digital textbooks to ensure such decisions will be supported.

Therefore, the study was primarily aimed at investigating mothers' attitudes toward the use of digital textbooks by their children. Despite its contribution to the e-learning field, the study was not free from limitations. Only mothers were surveyed, which means that the sample did not represent the male attitudes toward use of digital textbooks. Parents of older children may have different attitudes.

Results showed that all families participating in the study have digital devices at home and their children can use them. The majority of the participants' elementary-school children own their own digital devices, which means that part of the infrastructure needed for transforming to the digital textbook is already available. Only a small proportion of children whose mothers participated in the study did not use digital devices for learning. This means that most of the families were aware of the potential of digital devices to provide learning opportunities. 
In regard to the children's use of digital devices, results showed that children of almost all participants are using digital devices for watching videos. This entails more investigations of the use of videos in learning since children are already motivated in such activity.

In general, it can be stated that mothers have high positive attitudes toward their children's digital textbook use. The results suggest that mothers with children in elementary school support the use of digital textbooks by their children. The results mesh with results of other research (Nives, et al., 2016; Hatzigianni \& Margetts, 2014) in suggesting that mothers have positive attitudes toward using technology in their children's learning at early ages.

Results indicated high awareness of the drawbacks of digital textbooks when used by young students in education but even higher interest in using them. Participant mothers believe that digital textbooks improve their children's learning in general and are thus willing to switch from printed books to digital ones. Concerns that parents shared were that digital textbooks might affect their children's health and social lives which is in line with the results of previous studies on parents' concerns (Nives, et al., 2016; Hatzigianni \& Margetts, 2014). Qualitative data collected by open-ended questions showed concerns that using digital textbooks might negatively impact children's hand-writing and spelling skills and might negatively impact retention of information.

Even though the idea of using digital textbooks was accepted and welcomed by mothers, only $8 \%$ of the participants had their children read e-books. Exploring the reasons for not using e-books might be of interest to decision makers and may help in the transition to digital textbooks.

\section{Conclusion:}

The study aimed to determine mothers' attitudes toward their children use of digital textbooks in education. It aimed to answer the research question: What are the mothers' attitudes of the advantages and disadvantages of using e-books in education? Results indicated that parents, namely mothers, supported the use of digital textbooks but were aware of their drawbacks as well.

Although results of the study are promising, more extensive study should include male and female parents whose children are in different levels of education in K-12, in both rural areas and big cities in Saudi Arabia. Studies should be conducted to improve the validity of the results and determine parents' attitudes and concerns regarding digital textbooks in education. Such information may help decision makers to identify major strengths, weaknesses and implications of using digital textbooks. 


\section{References:}

Al Saadi, K., Lane-Kelso, M., Al Hafeedh, A., Al Sheithani, Z., \& Al Wishahi, M. (2017). Are we ready for E-Books? Omani University students' uses and perceptions of E-Books. Turkish Online Journal of Educational Technology-TOJET, 16(2), 11-25.

Alsahly, N. (2017). Replacing printed books with digital form in 2020. Al-Jazerh. Retrieved from http://www.al-jazirah.com/2017/20170330/lp3.htm

Anderson-Inman, L., \& Horney, M. (1997). Electronic books for secondary students. Journal of Adolescent \& Adult Literacy, 40(6), 486-491.

Buzzetto-More, N., Sweat-Guy, R., \& Elobaid, M. (2007). Reading in a digital age: E-books, are students ready for this learning object? Interdisciplinary Journal of Knowledge and Learning Objects, 3, 239-250.

Cavanaugh, T. (2003). E-books and accommodations. Is this the future of print accommodation? Teaching Exceptional Children, 35(2) 56-61.

Doering, T., Pereira, L. \& Kuechler, L. (2012). The use of e-textbooks in higher education: A case study. ELeader Berlin. 1-16.

Embong, A., Noor, A., Rafek, Othman, \& Khalid, P. (2014). What do teachers and pupils say about using e-books in the classrooms? International Journal of Social Science and Humanity, 4(6), 451.

Falc, E. (2013). An assessment of college students' attitudes towardtoward using an online e-textbook. Interdisciplinary Journal of E-Learning and Learning Objects, 9, 1-12.

Hatzigianni, M., Margetts, K. (2014). Parents' beliefs and evaluations of young children's computer use. Australasian Journal of Early Childhood,39 (4), 114-122.

Kiriakova, M., Okamoto, K. S., Zubarev, M., \& Gross, G. (2010). Aiming at a moving target: Pilot testing e-book readers in an urban academic library. Computers in Libraries, 30, 20-24.

Lam, P., Lam, S., Lam, J. \& McNaught, C. (2009). Usability and usefulness of ebooks on PPCs: How students' opinions vary over time .Australasian Journal of Educational Technology, 25(1), 30-44.

Li, C., Poe, F., Potter, M., Quigley, B., \& Wilson, J. (2011). UC Libraries academic e-book usage survey. USA: University of California, Springer eBook Pilot Project.

Liaw, S.-S. \& H.-M. Huang (2014). Investigating learner attitudes toward ebooks as learning tools: Based on the activity theory approach. Interactive Learning Environments, 1-19.

Lim, E. \& Hew, K. (2014). Students' perceptions of usefulness of an e-book with annotative and sharing capabilities as a tool for learning: A case study. Innovations in Education and Teaching International, 51 (1), 34-35.

Nives, M., Gordana, L., \& Mirjana, S. (2016). Investigating parents' attitudes towardtoward digital technology use in early childhood: A case study from Croatia. Information in Education 15(1),127-14.

Rao, S. (2003). Electronic books: A review and evaluation. Library Hi Tech, 27(1), 85-93. 
Shiratuddin, N. Landoni,M. Gibb, F. \& Hassan, S. (2003). E-book technology and its potential applications in distance education. Journal of Digital Information, 3(4).

Simon, E. J. (2001) Electronic textbooks: A pilot study of student e-reading habits. Future of Print Media Journal. 1-5.

Strano, M., Hrachovec, H., Sudweeks F., and Ess, C. (2012). Proceedings cultural attitudes TowardTowardtoward technology and communication. Australia: Murdoch University.

Sun, J., Flores, J. \& Tanguma, J. (2012). E- Textbooks and students' learning experiences. Decision Sciences Journal of Innovative Education, 10 (1), 63-77.

Weber. C. \& Cavanaugh, T. (2006). Using e-books with gifted and advanced readers. Gifted Child Today. 29(4).

Wilson, R. (2003). E-book readers in higher education. Educational Technology \& Society, 6 (4), 8-17.

Winters, C. (2005). Informed insight: Parental attitudes toward technology. Retrieved from: http://www.techlearning.com/news/0002/informedinsight-parental-attitudes-toward-technology/62485

Woody, W. D., Daniel, D. B., \& Baker, C. A. (2010). E-books or textbooks: Students prefer textbooks. Computers \& Education, 55, 945-948.

$\mathrm{Wu}, \mathrm{M}$. \& Chen, S. (2011). Graduate students' usage of and attitudes towardtoward e-textbooks: Experiences from Taiwan Program: Electronic Library and Information Systems, 45(3), 294-307.

Young, J. (2009). 6 lessons on campus learned about e-textbooks. The Chronicle of Higher Education, 55(39), A18 
العدد التاسع عثر لسنة ^1 ـ ب

ATH

مجلة البحث العلمى فى التربية 